\title{
Trabalhando com palavras de Dylan Thomas
}

Ivan Justen Santana

Dylan Thomas (1914-53), poeta nascido no País de Gales, chegou ao estrelato literário graças ao teor surpreendente de sua poesia. Valendo-se dos múltiplos recursos acumulados por vários séculos de poesia em língua inglesa, Thomas contribuiu a esse repertório com metáforas e com uma imagística inusitadas.

Aqui temos um poema sobre a ânsia de escrever poesia, escrito presumivelmente depois do poeta ter passado três meses longe de seu ofício. 


\section{On no work of words}

On no work of words now for three lean months in the bloody Belly of the rich year and the big purse of my body I bitterly take to task my poverty and craft:

To take to give is all, return what is hungrily given

Puffing the pounds of manna up through the dew to heaven, The lovely gift of the gab bangs back on a blind shaft.

To lift to leave from the treasures of man is pleasing death

That will rake at last all currencies of the marked breath

And count the taken, forsaken mysteries in a bad dark.

To surrender now is to pay the expensive ogre twice.

Ancient woods of my blood, dash down to the nut of the seas If I take to burn or return this world which is each man's work. 


\section{Sem trabalhar com palavras}

Sem trabalhar com palavras já por três meses magros na barriga

Maldita do ano rico e na grande bolsa da minha vida

Amargamente ponho em jogo minha pobreza e engenhosidade:

Pegar pra entregar é tudo, devolver o que é esfomeadamente dado

Soprando aos céus os quilos de maná através do orvalho,

adorável dom da verve reverbera num dente cego de engrenagem.

Levantar pra partir dos tesouros humanos é morte que agrada

E vai varrer enfim todos os dinheiros da respiração marcada,

Contabilizando os apanhados, abandonados mistérios no escuro atroz.

Capitular agora é pagar em dobro ao ogro gastador.

Bosques ancestrais de meu sangue, atirem-se ao caroço do mar

Se eu queimar ou devolver esse mundo que é o trabalho de cada um de nós. 
Algumas observações podem ajudar na compreensão e fruição tanto do original quanto da tradução. O leitor já deve ter notado que as imagens de Thomas são mesmo inusitadas, e também que seu vocabulário é diversificado. As metáforas estão por toda a parte, boa parte delas colocando valores comerciais em substituição aos de outra ordem (rich year, big purse of my body, the pounds of manna, treasures of man, currencies of breath, the expensive ogre, o uso dos verbos count e pay). Vejamos em detalhe mais algumas metáforas.

O maná que aparece no segundo terceto pode ser interpretado como a poesia, que é dada pelos céus para ser soprada de volta, numa ação que metaforiza o fazer poético.

O terceiro verso desse terceto traz outra metáfora dessa mesma ação: a poesia (the lovely gift of the gab ou "o adorável dom da verve") simplesmente ricocheteia no poeta, metaforizado como a blind shaft (shaft pode signicar literalmente uma lança, ou, em gíria, um comentário satírico depreciativo).

Minha tradução tomou certa liberdade nesse ponto, assim como em outros versos, em busca de efeitos surpreendentes e de manter o esquema de rimas. Usei rimas assonantes e também, a exemplo de Thomas (twice rimando com seas) rimei apenas a consoante final em "gastador" com "mar".

Espero que os leitores se dêem por satisfeitos com esses comentários e partam pra cima do poema de Thomas novamente, e que procurem fruir também as demais obras desse bardo. Vai valer o esforço.

Ivan Justen Santana é curitibano, mestrando em tradução literária pela USP. 